\title{
IMPLEMENTASI SAK EMKM DAN KEPATUHAN WAJIB PAJAK PELAKU UMKM DI KOTA MATARAM
}

\author{
Elvina Setiawati \\ Program Studi Akuntansi, Sekolah Tinggi Ilmu Ekonomi AMM, Jl. Pendidikan Nomor 1 \\ Mataram, Lombok, Nusa Tenggara Barat, 83125, Indonesia \\ E-mail: elvinasetiawati74@gmail.com
}

\begin{abstract}
This study aims to examine and analyze the effect of understanding the financial accounting standard for MSMEs (or SAK EMKM) and readiness for implementing it on taxpayer compliance. The data are collected through questionnaires on MSMEs in the Mataram City and analyzed by multiple linear regression. The results show that the understanding of SAK EMKM has a positive and significant effect on taxpayer compliance but the readiness to implement SAK EMKM is insignificant on taxpayer compliance. Basically, MSMEs in Mataram City are quite familiar with SAK EMKM, but due to the lack of human resources in the accounting sector, the implementation of SAK EMKM has not been fully implemented. This of course will give difficulties to the MSMEs in the Mataram City in preparing financial reports so that it will affect the accurate and correct tax calculation. In other words, the tax report is not submitted on time.
\end{abstract}

Keywords: understanding; readiness; implementation; SAK EMKM; taxpayer; compliance; Indonesia; Mataram City

\section{PENDAHULUAN}

Sebagai negara berkembang, Indonesia memiliki pangsa pasar potensial bagi perusahaan-perusahaan besar di dunia dan telah memasuki pasar bebas APEC bersama 21 negara lainnya di kawasan Asia Pasifik pada tahun 2020. Menurut Dewi dan Sari (2019), sangatlah penting bagi Indonesia untuk meningkatkan komoditi dengan langkah awal membangkitkan perekonomian bangsa dari sektor yang paling dasar yaitu Usaha Mikro, Kecil dan Menengah (UMKM). Dalam kondisi kompetitif saat ini, pengembangan UMKM merupakan salah satu langkah baik dalam upaya memerangi kemiskinan dan pengangguran di Indonesia. Data Kementerian Koperasi, Usaha Kecil dan Menengah menunjukkan bahwa jumlah UMKM terus mengalami peningkatan di Indonesia dan telah mencapai 99,99\% atau sekitar 64.194.057 unit pada tahun 2018, mampu mempekerjakan sebanyak 97\% dari total tenaga kerja Indonesia (UMKM dan Unit Besar) atau sekitar 116.978.631 orang dan memberikan kontribusi mencapai 57,8\% terhadap produk domestik bruto (PDB) di Indonesia (Jayani, 2020). Kota Mataram memiliki jumlah UMKM mencapai 58.146 unit pada tahun 2018 atau mengalami perkembangan sebanyak 12,048\% dibandingkan tahun sebelumnya (https://diskop.ntbprov.go.id). Data tersebut menunjukkan bahwa sektor UMKM dipandang sebagai salah satu sektor penggerak perekonomian di Indonesia. Secara konsisten, Divianto dan Febrianty (2017) menyatakan bahwa ketika terjadi krisis global pada tahun 2008, UMKM dipandang sebagai katup penyelamat dalam proses recovery ekonomi nasional, baik dalam hal upaya menahan gejolak krisis dan menopang perekonomian maupun mendorong laju pertumbuhan ekonomi serta penyerapan tenaga kerja.

Pada tahun 2008, Pemerintah Indonesia menerbitkan Undang-Undang Nomor 20 sebagai bentuk kepedulian dan perhatian pemerintah terhadap sektor UMKM. UndangUndang tersebut menjelaskan bahwa UMKM adalah usaha ekonomi produktif yang berdiri 
sendiri dan dilakukan oleh perseorangan atau badan usaha yang bukan merupakan anak perusahaan atau cabang perusahaan yang dimiliki, dikuasai atau menjadi bagian baik langsung maupun tidak langsung dengan usaha kecil atau besar. Dengan adanya peraturan yang menjadi payung hukum, gerak UMKM menjadi semakin leluasa dimana dalam peraturan tersebut tercantum mengenai perluasan pendanaan dan fasilitasi oleh perbankan dan lembaga jasa keuangan non-bank (LPPI dan Bank Indonesia, 2015:1-2). Perbankan pun mulai agresif dalam penyaluran kredit kepada UMKM dan tidak lagi memandang bisnis UMKM sebagai bisnis kelas dua. Misalnya, melalui Peraturan Bank Indonesia (PBI) yang dikeluarkan oleh Bank Sentral Nomor 14/22/PBI/2012 tanggal 21 Desember 2012 tentang Pemberian Kredit oleh Bank Umum dan Bantuan Teknis dalam Rangka Pengembangan Usaha Mikro, Kecil dan Menengah, mengamanatkan kepada bank agar pada tahun 2015 memberikan porsi kredit sekurang-kurangnya 5\% kepada UMKM dari total kredit atau pembiayaan yang dikucurkan. Bahkan pada tahun 2018, rasio kredit atau pembiayaan terhadap UMKM ditetapkan paling rendah $20 \%$ dari total kredit atau pembiayaan.

Walaupun peraturan sudah tertuang dengan jelas, namun bank umum cenderung menganggap pemberian kredit kepada UMKM lebih berisiko menimbulkan gagal bayar karena kredibilitas yang masih rendah, sehingga untuk meminimalisir risiko tersebut, perlu dilakukan analisis terhadap laporan keuangan UMKM untuk menilai kemampuan UMKM dalam melunasi kredit (Fettry et al., 2019). Di sisi lain, adanya laporan keuangan dapat memberikan informasi tentang posisi keuangan, kinerja dan arus kas yang bermanfaat bagi pengguna laporan keuangan dan menjadi bentuk pertanggungjawaban manajemen atas penggunaan sumber daya yang dipercayakan kepada mereka (Lestari, 2019; Salmiah et al., 2018). Namun kenyataannya, masih banyak UMKM justru tidak membuat dan menyajikan laporan keuangan dengan alasan laporan keuangan tidak terlalu dibutuhkan dan lebih berorientasi pada aktivitas operasi usaha yaitu bagaimana cara untuk meningkatkan omzet penjualan (Risal et al., 2020). Alasan lainnya adalah masih minimnya dan bahkan belum memiliki sumber daya yang kompeten di bidang akuntansi yang menyusun laporan keuangan dengan baik dan benar maupun beberapa pengusaha UMKM belum memisahkan antara uang pribadi dan uang usaha (Lestari, 2019; Fettry et al., 2019; Sholikin dan Setiawan, 2018). Di sisi lainnya, ada sebagian UMKM yang membuat laporan keuangan tetapi belum memenuhi kaidah akuntansi ataupun standar yang telah ditetapkan. Akibatnya, jika UMKM dipaksakan untuk membuat laporan keuangan maka laporan keuangan yang dihasilkan menjadi tidak relevan dan reliabel dalam pengambilan keputusan.

Atas dasar hal itu, Dewan Standar Akuntansi Keuangan (DSAK) telah menyusun dan mengesahkan Standar Akuntansi Keuangan Entitas Mikro Kecil dan Menengah (SAKEMKM) yang mulai berlaku sejak tanggal 1 Januari 2018. SAK EMKM ini ditujukan untuk entitas yang tidak atau belum mampu memenuhi persyaratan akuntansi yang diatur dalam SAK ETAP dan disusun sesuai dengan kebutuhan dan skala aktivitas bisnis pelaku UMKM mengingat bahwa SAK ETAP yang sebelumnya diterbitkan pada 1 Januari 2009, implementasinya justru tidak sesuai dengan entitas bisnis yang berskala mikro dan kecil. Dasar pengukuran SAK EMKM adalah biaya historis dan laporan keuangan minimum yang disajikan terdiri dari laporan keuangan posisi keuangan pada akhir periode, laporan laba rugi selama periode, maupun catatan atas laporan keuangan yang berisi informasi tambahan dan rincian yang disajikan bergantung pada jenis kegiatan usaha yang dilakukan oleh entitas. Penerapan SAK EMKM diharapkan memudahkan pelaku UMKM dalam penyusunan laporan keuangan yang berkualitas dan sesuai standar sehingga pelaku UMKM dapat mengembangkan aktivitas bisnisnya dengan pengambilan keputusan yang lebih baik (Qimyatussa' adah et al., 2020).

Salah satu peran UMKM dalam menunjang pembangunan negara adalah melalui kontribusinya dalam pembayaran pajak karena seperti yang diketahui bahwa berdasarkan 
Undang-Undang Nomor 16 Tahun 2009, pajak adalah salah satu sumber penerimaan sektor internal negara yang terutang oleh orang pribadi atau badan yang bersifat memaksa berdasarkan Undang-Undang, dengan tidak mendapatkan imbalan secara langsung dan digunakan untuk keperluan negara bagi sebesar-besarnya kemakmuran rakyat. Peraturan pajak tentang UMKM telah diatur dalam Peraturan Pemerintah Nomor 23 Tahun 2018 yang merupakan revisi dari Peraturan Pemerintah Nomor 46 Tahun 2013 tentang pajak penghasilan atas penghasilan dari usaha yang diterima atau diperoleh wajib pajak yang memiliki peredaran bruto tertentu. Dalam aturan baru tersebut, diatur penurunan tarif yang semula $1 \%$ menjadi $0,5 \%$. Dengan adanya penurunan tarif pajak UMKM maka akan meningkatkan kepatuhan wajib pajak UMKM. Kepatuhan wajib pajak dalam hal ini didefinisikan keadaaan saat dimana wajib pajak patuh dan sadar dalam memenuhi dan melaksanakan kewajiban perpajakannya sesuai dengan ketentuan peraturan perundangundangan seperti mengisi formulir pajak dengan lengkap dan jelas, menghitung dengan benar jumlah pajak yang terutang maupun membayar pajak yang terutang dengan tepat waktu (Mardiasmo, 2018:3).

Peraturan Pemerintah Nomor 23 Tahun 2018 memberikan batasan waktu pemanfaatan tarif pajak penghasilan $0,5 \%$ yaitu 7 tahun untuk wajib pajak orang pribadi, 4 tahun untuk wajib pajak badan dengan bentuk koperasi, CV atau Firma dan 3 tahun bagi wajib pajak badan yang berbentuk Perseroan Terbatas, sehingga setelah batasan waktu tersebut wajib pajak termasuk di dalamnya UMKM akan kembali menggunakan skema Undang-Undang Pajak Penghasilan pasal 17 dan tentunya akan membawa konsekuensi bagi UMKM untuk menyelenggarakan pembukuan agar menghasilkan laporan keuangan (Fettry et al., 2019). Laporan keuangan yang dihasilkan haruslah berkualitas agar informasi yang disampaikan tidak bias sehingga pelaku UMKM sangatlah penting memiliki pemahaman akuntansi yang baik dan tinggi, karena semakin tinggi tingkat pemahaman akuntansi pelaku UMKM maka akan menghasilkan laporan keuangan yang berkualitas pula dan tentu penyajiannya akan sesuai standar akuntansi yang berlaku. Dengan demikian, keadaan keuangan akan menjadi lebih jelas dan dapat dijadikan sebagai dasar dalam pengambilan keputusan ekonomi (Risal et al., 2020).

Terbitnya standar akuntansi untuk EMKM membuat para pelaku UMKM untuk memahami penerapan standar akuntansi tersebut dalam penyusunan laporan keuangan. Bukti empiris dari Putra (2018) dan Qimyatussa'adah et al. (2020) menunjukkan bahwa pemahaman pelaku UMKM terhadap standar akuntansi EMKM cenderung masih rendah dan sebagian besar belum mengimplementasikannya sehingga hal ini menunjukkan pentingnya peningkatan pemahaman akuntansi bagi pelaku UMKM melalui kegiatan pelatihan maupun sosialisasi oleh instansi pemerintah, akademisi, dan Dewan Pembuat Standar Akuntansi (DSAK). Pemahaman akuntansi sangatlah berkaitan erat dan berpengaruh terhadap kepatuhan wajib pajak. Dartini dan Jati (2016), dan Sumianto dan Kurniawan (2015) menunjukkan bahwa pemahaman atas pencatatan yang benar dan sesuai standar akuntansi yang berlaku menyebabkan pengusaha dapat mengukur tingkat pendapatan dan pengeluaran dari usaha yang dijalankan sehingga mampu mengukur keuntungan dengan tepat dan menghitung pajak yang akan disetorkan dengan benar. Pemahaman akuntansi yang kuat dan sesuai dengan standar akuntansi akan membentuk pengetahuan yang mendorong secara sukarela kepatuhan wajib pajak. Darmawati dan Oktaviani (2018) menemukan bahwa adanya penerapan akuntansi yang memadai dapat meningkatkan reliabilitas laporan keuangan dan menyebabkan kemudahan dalam penghitungan pajak terutang yang selanjutnya berdampak pada meningkatnya kepatuhan wajib pajak. Fakta-fakta ini menunjukkan bahwa pelaku UMKM haruslah mempersiapkan diri untuk segera mengimplementasikan SAK EMKM. Menurut Dewi dan Sari (2019), kesiapan adalah suatu kemampuan yang dimiliki seseorang untuk melakukan sesuatu sesuai dengan situasi kondisi yang ada. Dengan kata lain, kesiapan dilihat 
dari keadaan seseorang yang dalam hal ini adalah pelaku UMKM yang membuatnya siap untuk mengimplementasikan laporan keuangan berbasis SAK EMKM. Jika pelaku UMKM menganggap pentingnya implementasi SAK EMKM dalam penyusunan laporan keuangan disertai dengan adanya fasilitas pendukung, maka laporan keuangan yang dihasilkan akan berkualitas dan mencerminkan keadaan yang sebenarnya sehingga hal ini tentunya akan mempermudah pelaku UMKM dalam memenuhi kewajiban perpajakannya seperti menghitung, menyetor, dan melaporkan jumlah pajak yang terutang. Penelitian tentang dampak pemahaman SAK EMKM dan kesiapan implementasi SAK EMKM terhadap kepatuhan wajib pajak masih terbatas. Penelitian sebelumnya lebih banyak berfokus dari sisi analisis tingkat pemahaman dan tingkat kesiapan implementasi standar akuntansi pada pelaku UMKM, sehingga penelitian ini bertujuan untuk mengkaji bagaimana pengaruh pemahaman dan kesiapan implementasi SAK EMKM terhadap kepatuhan wajib pajak UMKM yang ada di Kota Mataram. Kontribusi penelitian ini adalah memberikan bukti empiris bagi para pelaku UMKM bahwa dalam menyusun laporan keuangan yang baik dan benar haruslah disesuaikan dengan standar akuntansi keuangan yang berlaku bagi entitas mikro, kecil dan menengah. Hal ini didasarkan pada asumsi bahwa penyusunan laporan keuangan sesuai standar berlaku akan menghasilkan laporan keuangan yang berkualitas dan akan meningkatkan keakuratan dan ketepatan laporan keuangan yang dapat digunakan sebagai dasar dalam penghitungan pajak. Asumsi lainnya adalah penerapan akuntansi yang ditunjukkan dengan pemahaman dan kesiapan implementasi SAK EMKM dalam penyusunan laporan keuangan akan memberikan kemudahan kerjasama terkait dengan keuangan seperti pendanaan dengan pihak ketiga seperti halnya Bank.

\section{TINJAUAN PUSTAKA}

Standar Akuntansi Entitas Mikro Kecil dan Menengah (SAK EMKM). Dalam upaya membantu UMKM memenuhi kebutuhan pelaporan keuangannya, maka DSAK dari Ikatan Akuntansi Indonesia (IAI) menerbitkan sebuah standar yang dikenal dengan SAK EMKM. Standar tersebut diperuntukkan bagi entitas mikro, kecil dan menengah yang menerbitkan laporan keuangan untuk tujuan umum bagi pengguna eksternal. Adapun laporan keuangan minimum yang dibuat sesuai standar tersebut terdiri atas laporan posisi keuangan, laporan laba-rugi, dan catatan atas laporan keuangan (Ikatan Akuntan Indonesia, 2016:2-8).

Pemahaman SAK EMKM. Pemahaman SAK EMKM merupakan suatu kemampuan seseorang untuk mengukur, mengklasifikasi (membedakan), dan mengikhtisarkan penyajian unsur-unsur laporan keuangan sesuai dengan ketentuan yang berlaku dalam SAK EMKM (Salmiah et al., 2018). Dalam penelitian ini, pemahaman SAK EMKM dapat dilihat dari sejauh mana pelaku UMKM memiliki pemahaman akuntansi dalam penerapan SAK EMKM yang mencakup pengukuran (biaya historis), asumsi dasar (dasar akrual, kelangsungan usaha, dan konsep entitas bisnis), maupun penyajian laporan keuangan (laporan laba/rugi, laporan posisi keuangan, dan catatan atas laporan keuangan).

Kesiapan implementasi SAK EMKM. Menurut business dictionary yang dikutip dari Dewi dan Sari (2019), kesiapan adalah pernyataan siap dari seseorang, sistem atau organisasi untuk memenuhi dan melaksanakan sebuah kegiatan yang terencana. Dengan kata lain, kesiapan berarti keseluruhan kondisi yang membuat seseorang untuk siap dalam hal memberi respon atau jawaban di dalam cara tertentu terhadap suatu situasi. Dalam penelitian ini, kesiapan dilihat dari sejauh mana pelaku UMKM sudah bersedia untuk menerapkan SAK EMKM yang mencakup persepsi pelaku UMKM dan adanya fasilitas pendukung meliputi pentingnya SAK EMKM, adanya catatan transaksi berbasis akrual, adanya pemisahan antara keuangan perusahaan dengan keuangan pribadi, dan adanya sumber daya manusia yang memiliki keahlian di bidang akuntansi. 
Kepatuhan wajib pajak. Menurut Febriani dan Kusmuriyanto (2015), kepatuhan wajib pajak ditandai dengan keadaan saat wajib pajak memenuhi semua kewajiban perpajakan dan melaksanakan hak perpajakannya. Prinsip yang dianut dalam hal ini adalah self assessment system yaitu wajib pajak mendaftarkan diri, mencatat semua penghasilan kena pajak, membayar pajak terutang hingga melaporkan pajak sesuai dengan ketentuan peraturan perundang-undangan. Dalam penelitian ini, kepatuhan wajib pajak dilihat dari kesadaran dan kemauan wajib pajak dalam memenuhi kewajiban perpajakannya yang mencakup kepemilikan NPWP, penyampaian SPT Tahunan tepat waktu, pelaporan semua pendapatan dalam SPT Tahunan, dan adanya tunggakan pajak.

Pemahaman SAK EMKM dan kepatuhan wajib pajak. Sejak diterapkan dan diberlakukannya SAK EMKM sebagai pedoman dalam penyusunan laporan keuangan bagi UMKM, maka UMKM perlu lebih memahami penerbitan UMKM sebagai dasar penyusunan laporan keuangan. Pemahaman SAK EMKM merupakan suatu kemampuan seseorang untuk mengukur, mengklasifikasi (membedakan), dan mengikhtisarkan penyajian unsur-unsur laporan keuangan sesuai dengan ketentuan yang berlaku dalam SAK EMKM (Pulungan, 2020). Hal ini berarti bahwa pemahaman terhadap SAK EMKM berkaitan dengan pemahaman akuntansi yang dimiliki seseorang dimana jika pelaku UMKM telah memiliki pemahaman akuntansi yang baik dan benar maka akan mampu menyusun laporan keuangan sesuai dengan standar yang ditetapkan. Dengan demikian, laporan keuangan komersial yang dihasilkan dari pemahaman akuntansi akan diperlukan untuk menghitung jumlah penghasilan kena pajaknya setelah dilakukan koreksi fiskal sesuai dengan ketentuan peraturan perpajakan (Pakpahan, 2015). Hal yang sama disampaikan oleh Azmary et al. (2020) bahwa adanya penerapan akuntansi UMKM dengan baik dan sesuai standar maka akan membantu dalam hal penyusunan laporan keuangan dengan benar dan tepat sehingga akan mempermudah dalam penghitungan jumlah pajak yang terutang. Hal ini tentunya akan berdampak pula terhadap tingkat kepatuhan wajib pajak yang semakin tinggi dalam menghitung, membayar, dan melaporkan jumlah pajak terutang yang harus dibayar. Pernyataan tersebut sejalan dengan Dartini dan Jati (2016) bahwa pemahaman akuntansi yang kuat dan sesuai dengan standar akuntansi akan membentuk pengetahuan yang mendorong secara sukarela kepatuhan wajib pajak dan menjadi dasar dalam penghitungan tingkat pajak terutang secara benar. Secara konsisten, Darmawati dan Oktaviani (2018) juga menyatakan bahwa apabila wajib pajak memiliki pemahaman akuntansi yang semakin baik maka akan mendorong wajib pajak menaati kepatuhan perpajakannya dikarenakan dengan pemahaman akuntansi akan mempermudah dalam melakukan pembukuan yang menghasilkan laporan keuangan sesuai standar akuntansi yang berlaku dan digunakan sebagai dasar pembuatan laporan fiskal pajak dan tentunya akan memberikan pengaruh terhadap peningkatan kepatuhan wajib pajak. Sumianto dan Kurniawan (2015) menemukan bahwa pemahaman akuntansi UKM yang ditandai dengan pemahaman cara pencatatan yang benar dan baik sesuai standar akuntansi akan meningkatkan kepatuhan wajib pajak, sebab pengusaha dapat mengukur tingkat pendapatan dan pengeluaran dari usaha yang dijalankan sehingga mengetahui keuntungan dalam usahanya dengan tepat dan tentunya dapat menghitung pajak yang akan disetorkan dengan benar. Berdasarkan uraian tersebut, dapat dirumuskan hipotesis sebagai berikut:

$H_{1}$ : Pemahaman SAK EMKM berpengaruh positif dan signifikan terhadap kepatuhan wajib pajak

Kesiapan implementasi SAK EMKM dan kepatuhan wajib pajak. Informasi akuntansi mempunyai peranan yang sangat penting bagi UMKM dalam hal mencapai keberhasilan usaha. Adanya SAK EMKM akan membantu UMKM lebih maju dan mandiri terutama dalam hal menyelenggarakan pencatatan atas laporan keuangan usahanya (Sutapa, 2020). Untuk dapat mengoptimalkan implementasi SAK EMKM maka UMKM perlu lebih siap atas penerbitan SAK EMKM sebagai dasar penyusunan laporan keuangan. Kesiapan 
berarti keadaan pengelola UMKM yang membuatnya siap untuk memberikan jawaban dengan pengetahuan yang dimilikinya dimana dapat dilihat dari wawasan pengelola UMKM tentang laporan keuangan dan SAK EMKM (Pulungan, 2020). Lestari (2019) menemukan bahwa tiga objek UMKM dalam penelitiannya belum siap menerapkan SAK EMKM dalam penyusunan laporan keuangannya dikarenakan belum memahami dan mengetahui tentang SAK EMKM maupun tidak ada pegawai khusus yang menyelenggarakan pembukuan. Qimyatussa'adah et al. (2020) juga menemukan bahwa hanya sebagian kecil dari responden telah memahami SAK EMKM sehingga sebagian besar dari responden tidak menerapkan SAK EMKM dalam penyusunan laporan keuangannya, bahkan belum pernah menyusun laporan keuangan. Secara konsisten, Dewi dan Sari (2019) menemukan bahwa hampir seluruh pelaku usaha menengah mengetahui tentang dasar akuntansi serta aturan mengenai SAK EMKM sehingga telah siap dan mampu dalam menyusun laporan keuangan yang berkualitas. Berdasarkan bukti-bukti ini, maka hal ini berarti bahwa laporan keuangan yang berkualitas akan disusun oleh pelaku usaha yang memiliki pengetahuan dasar-dasar akuntansi dan sesuai standar akuntansi yang berlaku karena telah mengimplementasikan SAK EMKM dengan baik dan benar untuk dijadikan sebagai dasar penghitungan pajak yang terutang sesuai dengan ketentuan perpajakan berlaku dan dapat meningkatkan kepatuhan wajib pajak. Berdasarkan uraian tersebut, dapat dirumuskan hipotesis sebagai berikut:

$\mathrm{H}_{2}$ : Kesiapan implementasi SAK EMKM berpengaruh positif dan signifikan terhadap kepatuhan wajib pajak.

Berdasarkan hasil kajian literatur, rerangka konseptual dalam penelitian ini dapat digambarkan pada Gambar 1.

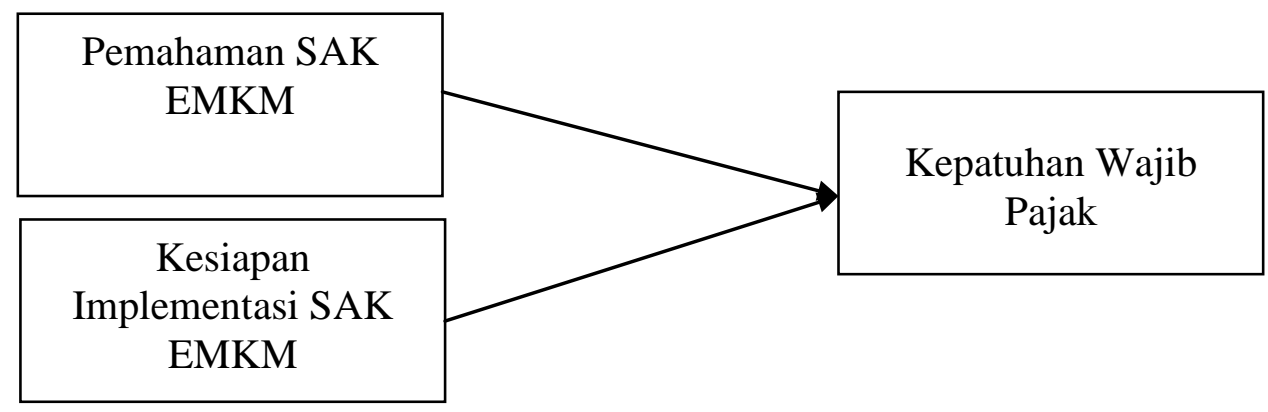

Gambar 1. Rerangka Konseptual

\section{METODE PENELITIAN}

Jenis dan sumber data. Penelitian ini menggunakan metode analisis kuantitatif dengan data yang berbentuk angka atau diukur dalam skala numerik. Sumber data dalam penelitian ini adalah data primer yaitu data yang diperoleh langsung dari sumbernya berupa hasil jawaban kuesioner yang sudah disebarkan kepada responden dalam hal ini adalah pelaku UMKM di Kota Mataram Provinsi Nusa Tenggara Barat, Indonesia.

Populasi, sampel, dan teknik pengambilan sampel. Populasi dalam penelitian ini adalah pelaku UMKM di Kota Mataram yang berjumlah 58.146. Penelitian ini mengambil jumlah sampel dengan menggunakan rumus Slovin sehingga diperoleh jumlah sampel sebesar 100 responden dimana teknik pengambilan sampel menggunakan teknik nonprobability sampling dengan sampling aksidental. Sampling aksidental adalah teknik penentuan sampel berdasarkan kebetulan, yaitu siapa saja yang secara kebetulan bertemu dengan peneliti dapat digunakan sebagai sampel, bila dipandang orang yang kebetulan ditemui itu sesuai sebagai sumber data (Sugiyono, 2019:118).

Metode analisis. Penelitian ini menggunakan metode analisis data berupa statistik deskriptif, uji validitas dan reliabilitas, uji asumsi klasik, dan regresi linear berganda. 
Berdasarkan uji regresi linear berganda, model persamaan penelitian ini dapat dinyatakan sebagai berikut:

Kepatuhan Wajib Pajak $=\alpha+\beta$.Pemahaman SAK EMKM + B.Kesiapan Implementasi SAK EMKM $+\varepsilon$

Deskripsi dilakukan atas persepsi responden terhadap pernyataan yang ditentukan berdasarkan persentase jawaban dengan menggunakan nilai rerata (mean) dari setiap item indikator yang diajukan. Persepsi yang dinyatakan oleh responden berkaitan dengan pemahaman terhadap SAK EMKM, kesiapan implementasi SAK EMKM, dan kepatuhan wajib pajak. Guna menganalisis jawaban responden, maka pada analisis deskripsi juga dilakukan kategorisasi terhadap rata-rata skor jawaban responden. Tabel 1 menyajikan rentang kategori nilai interval dalam penelitian ini dimana nilai skor tertinggi dalam penelitian ini adalah 5 (lima) dan nilai skor terendah adalah 1 (satu) yang berasal dari skala dalam kuesioner sehingga diperoleh interval kelas sebesar 0,8 (interval kelas $=(5-1) / 5$ ).

Tabel 1. Rentang kategori nilai interval

\begin{tabular}{cccc}
\hline Interval & $\begin{array}{c}\text { Kategori Variabel } \\
\text { Pemahaman SAK } \\
\text { EMKM }\end{array}$ & $\begin{array}{c}\text { Kategori Kesiapan } \\
\text { Implementasi SAK }\end{array}$ & $\begin{array}{c}\text { Kategori Kepatuhan } \\
\text { Wajib Pajak }\end{array}$ \\
\hline $1.00-1.80$ & Sangat Tidak Paham & Sangat Tidak Siap & Sangat Rendah \\
$1.81-2.60$ & Tidak Paham & Tidak Siap & Rendah \\
$2.61-3.40$ & Cukup Paham & Cukup Siap & Cukup Tinggi \\
$3.41-4.20$ & Paham & Siap & Tinggi \\
$4.21-5.00$ & Sangat Paham & Sangat Siap & Sangat Tinggi \\
\hline
\end{tabular}

Uji validitas dilakukan dengan melakukan korelasi bivariate antara masing-masing skor butir pernyataan dengan total skor dimana butir-butir pernyataan dinyatakan valid jika nilai signifikansi kurang dari 0.05 (Ghozali, 2013:53), sedangkan reliabilitas digunakan untuk mengukur apakah instrumen tersebut secara konsisten memberikan hasil ukur yang sama tentang sesuatu yang diukur pada waktu yang berlainan dimana jika nilai Cronbach's alpha lebih besar dari 0.60 maka instrumen dapat dinyatakan reliabel (Hair et al., 2009:60). Uji asumsi klasik pada penelitian ini terdiri dari: (1) uji normalitas yaitu untuk menguji apakah dalam model regresi, variabel pengganggu atau residual error memiliki distribusi normal yang dalam hal ini dilihat dengan Kolmogorov-Smirnov (Ghozali, 2013:160); (2) uji multikolinieritas yang bertujuan untuk menguji apakah model regresi ditemukan adanya korelasi antar variabel bebas (independen) yang dideteksi dengan dideteksi dengan menggunakan nilai tolerance dan Variance Inflation Factor (VIF) (Ghozali, 2013:106); dan (3) uji heteroskedastisitas yang bertujuan untuk menguji apakah dalam model regresi terjadi ketidaksamaan variance dari residual error satu pengamatan ke pengamatan yang lain dan dideteksi dengan uji Glejser (Ghozali, 2013:134). Uji regresi linier berganda dilakukan untuk menunjukkan arah hubungan dan mengukur kekuatan hubungan antara variabel independen (pemahaman SAK EMKM dan kesiapan implementasi SAK EMKM) terhadap variabel dependen (kepatuhan wajib pajak), dimana jika tingkat signifikansi kurang dari 0.05 dikatakan memiliki pengaruh signifikan variabel independen terhadap variabel dependen.

\section{HASIL PENELITIAN DAN PEMBAHASAN}

\subsection{Hasil penelitian}

Kuesioner disebarkan langsung kepada pelaku UMKM yang ada di Kota Mataram. Kuesioner yang berhasil disebar dan dianalisis lebih lanjut sebanyak 100, dalam arti semua 
kuesioner yang disebarkan kembali 100\%. Tabel 2 menyajikan karakteristik responden penelitian berdasarkan jenis kelamin, usia, pendidikan dan lama usaha.

Tabel 2. Karakteristik responden

\begin{tabular}{llcc}
\hline \multicolumn{2}{c}{ Karakteristik responden } & Jumlah & Persentase \\
\hline \multirow{2}{*}{ Jenis Kelamin } & Laki-laki & 56 & $56 \%$ \\
& Perempuan & 44 & $44 \%$ \\
\hline \multirow{2}{*}{ Tingkat pendidikan } & Pendidikan dasar & 9 & $9 \%$ \\
& Pendidikan menengah & 41 & $41 \%$ \\
& Pendidikan tinggi & 50 & $50 \%$ \\
\hline Umur & $21-40$ tahun & 50 & $50 \%$ \\
& $41-60$ tahun & 49 & $49 \%$ \\
& $61-80$ tahun & 1 & $1 \%$ \\
\hline Lama usaha & $<5$ tahun & 2 & $2 \%$ \\
& $5-10$ tahun & 40 & $40 \%$ \\
& $>10$ tahun & 58 & $58 \%$ \\
\hline
\end{tabular}

Tabel 3 menyajikan data persepsi responden terhadap pernyataan penelitian berkaitan dengan pemahaman SAK EMKM, kesiapan implementasi SAK EMKM dan kepatuhan wajib pajak dengan hasil bahwa nilai rata-rata persepsi responden sebesar 3,4 untuk penyataan pemahaman SAK EMKM (berkategori cukup paham), nilai rata-rata persepsi responden sebesar 3,1 untuk pernyataan implementasi SAK EMKM (berkategori cukup siap) dan nilai rata-rata persepsi responden sebesar 3,2 untuk pernyataan kepatuhan wajib pajak (berkategori sedang).

Tabel 3. Persepsi responden terhadap pemahaman SAK EMKM, kesiapan implementasi SAK EMKM, dan kepatuhan wajib pajak

\begin{tabular}{|c|c|c|c|c|c|c|}
\hline \multirow{3}{*}{ Item } & \multicolumn{6}{|c|}{ Total Skor } \\
\hline & \multicolumn{5}{|c|}{ Tingkat Penilaian Responden } & \multirow{2}{*}{$\begin{array}{l}\text { Rata-rata } \\
\text { Persepsi }\end{array}$} \\
\hline & $\mathbf{1}$ & 2 & 3 & 4 & 5 & \\
\hline \multicolumn{7}{|l|}{ Pemahaman SAK EMKM } \\
\hline $\mathrm{X}_{1.1}$ & 8 & 28 & 102 & 120 & 70 & 3.3 \\
\hline $\mathrm{X}_{1.2}$ & 8 & 32 & 102 & 100 & 85 & 3.3 \\
\hline $\mathrm{X}_{1.3}$ & 6 & 36 & 87 & 128 & 75 & 3.3 \\
\hline $\mathrm{X}_{1.4}$ & 6 & 30 & 78 & 116 & 120 & 3.5 \\
\hline $\mathrm{X}_{1.5}$ & 9 & 28 & 84 & 108 & 110 & 3.4 \\
\hline $\mathrm{X}_{1.6}$ & 8 & 26 & 72 & 132 & 110 & 3.5 \\
\hline $\mathrm{X}_{1.7}$ & 10 & 22 & 60 & 136 & 125 & 3.5 \\
\hline $\mathrm{X}_{1.8}$ & 9 & 28 & 129 & 72 & 80 & 3.2 \\
\hline Rerata $X_{1}$ & 8 & 29 & 89 & 114 & 97 & 3.4 \\
\hline \multicolumn{7}{|c|}{ Kesiapan implementasi SAK EMKM } \\
\hline $\mathrm{X}_{2.1}$ & 0 & 74 & 0 & 252 & 0 & 3.3 \\
\hline $\mathrm{X}_{2.2}$ & 0 & 90 & 0 & 0 & 275 & 3.7 \\
\hline $\mathrm{X}_{2.3}$ & 0 & 104 & 0 & 192 & 0 & 3.0 \\
\hline $\mathrm{X}_{2.4}$ & 0 & 146 & 0 & 108 & 0 & 2.5 \\
\hline Rerata $X_{2}$ & 0 & 10204 & 0 & 138 & 69 & 3.1 \\
\hline \multicolumn{7}{|l|}{ Kepatuhan wajib pajak } \\
\hline$Y_{1.1}$ & 0 & 20 & 0 & 360 & 0 & 3.8 \\
\hline $\mathrm{Y}_{1.2}$ & 0 & 128 & 0 & 0 & 180 & 3.1 \\
\hline $\mathrm{Y}_{1.3}$ & 0 & 158 & 0 & 84 & 0 & 2.4 \\
\hline $\mathrm{Y}_{1.4}$ & 0 & 52 & 0 & 296 & 0 & 3.5 \\
\hline Rerata Y & 0 & 90 & 0 & 185 & 45 & 3.2 \\
\hline
\end{tabular}


Uji validitas dan reliabilitas. Uji validitas adalah ukuran untuk menilai apakah alat ukur yang digunakan benar-benar mampu memberikan nilai dari variabel yang ingin diukur sedangkan uji reliabilitas digunakan untuk mengukur apakah instrumen tersebut secara konsisten memberikan hasil ukur yang sama tentang sesuatu yang diukur pada waktu yang berlainan. Tabel 4 menyajikan hasil uji validitas dimana semua indikator memiliki nilai korelasi dengan signifikansi lebih kecil dari 0.05 sehingga dapat dinyatakan valid sedangkan hasil uji reabilitas menunjukkan bahwa semua indikator kuesioner mempunyai nilai koefisien Cronbach's alpha lebih besar dari 0.6 sehingga dapat dikatakan bahwa semua indikator adalah reliabel.

Tabel 4 . Uji validitas dan reabilitas

\begin{tabular}{cccc}
\hline Item & $\begin{array}{c}\text { Pemahaman } \\
\text { SAK EMKM } \\
(\mathbf{X 1})\end{array}$ & $\begin{array}{c}\text { Kesiapan implementasi } \\
\text { SAK EMKM } \\
(\mathbf{X 2})\end{array}$ & $\begin{array}{c}\text { Kepatuhan wajib pajak } \\
(\mathbf{Y})\end{array}$ \\
\hline $\mathrm{X}_{1}$ & $0.901^{*}$ & $0.653^{*}$ & $0.591^{*}$ \\
$\mathrm{X}_{2}$ & $0.879^{*}$ & $0.777^{*}$ & $0.849^{*}$ \\
$\mathrm{X}_{3}$ & $0.886^{*}$ & $0.715^{*}$ & $0.670^{*}$ \\
$\mathrm{X}_{4}$ & $0.899^{*}$ & $0.686^{*}$ & $0.653^{*}$ \\
$\mathrm{X}_{5}$ & $0.890^{*}$ & & \\
$\mathrm{X}_{6}$ & $0.913^{*}$ & & \\
$\mathrm{X}_{7}$ & $0.899^{*}$ & & \\
$\mathrm{X}_{8}$ & $0.858^{*}$ & & \\
Cronbach's Alpha & 0.963 & 0.654 & \\
\hline *signifikan pada tingkat 0.05 & & &
\end{tabular}

Uji regresi linier berganda. Tabel 8 menunjukkan bahwa pemahaman SAK EMKM berpengaruh positif dan signifikan terhadap kepatuhan wajib pajak sehingga hipotesis pertama $\left(\mathrm{H}_{1}\right)$ diterima. Sebaliknya, kesiapan implementasi SAK EMKM tidak signifikan terhadap kepatuhan wajib pajak sehingga hipotesis kedua $\left(\mathrm{H}_{2}\right)$ ditolak. Nilai uji $\mathrm{F}$ menunjukkan model regresi adalah fit dan nilai adjusted $R$ square menunjukkan bahwa perubahan yang terjadi pada kepatuhan wajib pajak dapat dijelaskan oleh variabel pemahaman SAK EMKM dan kesiapan implementasi SAK EMKM sebesar 18.2 persen, sisanya sebesar 81.8 persen dijelaskan oleh faktor lain yang tidak diuji dalam penelitian ini. Selain itu, hasil uji asumsi klasik menunjukkan bahwa model regresi dapat diasumsikan sebagai Best Linear Unbiased Estimator (BLUE), dimana nilai Kolmogorov-Smirnov memiliki nilai signifikansi lebih besar dari 0.05 atau sebesar 0.849 sehingga dapat diasumsikan bahwa residual error dari model regresi terdistribusi secara normal. Lebih lanjut, uji multikolinearitas menunjukkan bahwa nilai tolerance pada seluruh variabel lebih besar daripada 0.10 dengan nilai VIF lebih kecil dari 10 sehingga dapat diasumsikan bahwa antar variabel independen tidak terjadi gejala multikolinearitas. Uji heteroskedastisitas dengan menggunakan uji Glejser menunjukkan bahwa nilai signifikansi variabel pemahaman SAK EMKM dan variabel kesiapan implementasi SAK EMKM berada diatas 0.05 sehingga varians residual error dari model regresi diasumsikan tidak terjadi gejala heteroskedastisitas. 
Tabel 5. Uji regresi berganda

\begin{tabular}{lcccc}
\hline \multicolumn{1}{c}{ Model } & \multirow{2}{*}{$\begin{array}{c}\text { Regression } \\
\text { coefficients }\end{array}$} & $\begin{array}{c}\text { Significance of } \\
\text { Glejser test }\end{array}$ & \multicolumn{2}{c}{$\begin{array}{c}\text { Collinearity } \\
\text { statistics }\end{array}$} \\
\cline { 5 - 6 } & & & Tolerance & VIF \\
\hline Constant & 8.353 & & & \\
Pemahaman SAK EMKM & $0.109^{*}$ & 0.466 & 0.505 & 1.982 \\
Kesiapan implementasi SAK EMKM & 0.121 & 0.137 & 0.505 & 1.982 \\
\hline Variabel dependen adalah kepatuhan wajib pajak & & & & \\
F test & & $12.019^{*}$ & & \\
R Square & & 0.199 & & \\
Adjusted R Square & 0.182 & & \\
Kolmogorov-Smirnov Z significance & & 0.849 & & \\
*signifikan pada tingkat 0.05 & & & &
\end{tabular}

\subsection{Pembahasan}

\section{Pemahaman SAK EMKM dan kepatuhan wajib pajak}

Hasil pengujian menunjukkan bahwa variabel pemahaman SAK EMKM berpengaruh positif dan signifikan terhadap tingkat kepatuhan wajib pajak sehingga hasil penelitian ini konsisten dengan Darmawati dan Oktaviani (2018), Dartini dan Jati (2016), Pakpahan (2015), dan Sumianto dan Kurniawan (2015). Hasil penelitian ini juga mendukung Darmawati dan Oktaviani (2018) dan Azmary et al. (2020) untuk membuktikan bahwa adanya pemahaman SAK EMKM yang baik dari UMKM mengindikasikan penerapan akuntansi yang baik dalam pengelolaan keuangan sehingga dapat menghasilkan laporan keuangan sesuai standar yang berlaku guna membantu pemerolehan informasi untuk kepentingan penghitungan pajak dan memenuhi kewajiban perpajakannya. Selain itu, penelitian ini konsisten dengan Darmawati dan Oktaviani (2018) untuk membuktikan bahwa kepatuhan wajib pajak cenderung mengalami peningkatan melalui penghitungan pajak terutang sebagai dampak dari penyajian laporan keuangan yang wajar berdasarkan pemahaman akuntansi yang baik. Penelitian ini mendukung Dartini dan Jati (2016) dan Salmiah et al. (2018) untuk membuktikan bahwa pemahaman akuntansi yang baik akan memberikan dampak positif dalam hal meningkatkan keyakinan penyusunan laporan keuangan yang wajar sesuai standar akuntansi yang berlaku guna menghindarkan wajib pajak dari kesalahan penghitungan dan penyusunan laporan pajak serta menjamin ketepatan waktu dan keyakinan dari wajib pajak dalam pelaporan pajak. Secara empiris, keyakinan dan ketepatan waktu dalam menyelesaikan kewajiban perpajakan menunjukkan adanya kepatuhan wajib pajak di Kota Mataram dimana para pelaku UMKM memiliki pemahaman yang cukup terhadap SAK EMKM baik dalam hal pengukuran, asumsi dasar, dan penyajian laporan keuangan. Selain itu, mayoritas tingkat pendidikan dari pelaku UMKM telah memadai yang berarti para pelaku UMKM telah memiliki pengetahuan yang cukup dalam menjalankan usahanya dan mampu mengakses informasi untuk mengembangkan usaha termasuk tentang SAK EMKM. Hasil penelitian ini juga menunjukkan bahwa para pelaku UMKM di Kota Mataram telah memiliki pengalaman dalam dunia usaha yang ditekuni karena sebagian besar usaha telah dijalankan lebih dari 10 tahun.

\section{Kesiapan implementasi SAK EMKM dan kepatuhan wajib pajak}

Hasil penelitian ini mendukung Fettry et al. (2019) dimana hasil pengujian menunjukkan bahwa kesiapan implementasi SAK EMKM tidak signifikan terhadap kepatuhan wajib pajak. Konsisten dengan Lestari (2019), hasil ini mengindikasikan bahwa UMKM di Kota Mataram belum cukup memiliki sumber daya manusia profesional sehingga implementasi SAK EMKM belum diterapkan secara optimal khususnya dalam hal penyusunan laporan keuangan secara profesional walaupun pengelolaan keuangan secara sederhana untuk kepentingan perpajakan telah dilakukan dengan baik. Kecenderungan 
lainnya adalah belum cukupnya sumber daya manusia profesional yang mampu menyusun laporan keuangan disebabkan belum adanya tuntutan dari para pengguna laporan keuangan seperti kreditur. Pada umumnya, pelaku UMKM di Kota Mataram yang membutuhkan bantuan permodalan dari perbankan lebih memanfaatkan dana Kredit Usaha Rakyat (KUR) dimana pengajuan dana tersebut tidak mensyaratkan laporan keuangan UMKM. Secara empiris, para pelaku UMKM di Kota Mataram telah memiliki tingkat pendidikan yang memadai sehingga memiliki kepatuhan wajib pajak yang cukup serta mampu memahami pentingnya implementasi SAK EMKM untuk memenuhi kebutuhan pelaporan keuangan.

\section{KESIMPULAN DAN SARAN}

\subsection{Kesimpulan}

Pemahaman akuntansi yang baik melalui pemahaman SAK EMKM dapat memberikan kualitas pencatatan akuntansi yang baik dalam menghasilkan laporan keuangan yang wajar sesuai standar berlaku terlebih khusus untuk penyusunan laporan fiskal untuk kepentingan perpajakan. Pelaku UMKM dengan pemahaman akuntansi yang baik mampu menjalankan kewajiban perpajakannya sehingga cenderung memiliki kepatuhan pajak yang lebih tinggi. Akan tetapi, tidak cukupnya ketersediaan sumber daya manusia bagi UMKM di Kota Mataram cenderung dapat mengakibatkan UMKM tersebut mengalami kesulitan dalam penyusunan laporan keuangan formal dan penghitungan pajak sehingga dapat menghambat pelaporan perpajakan dan mempengaruhi kepatuhan UMKM sebagai wajib pajak.

\subsection{Saran}

Penelitian ini terbatas dalam wilayah Kota Mataram sehingga tidak berlaku umum untuk semua wilayah yang ada di Nusa Tenggara Barat karena setiap wilayah memiliki karakteristik yang berbeda sehingga memerlukan penelitian lanjutan pada objek yang berbeda. Pentingnya pemahaman SAK EMKM dan implementasinya bagi UMKM membutuhkan peran dari semua pihak seperti pemerintah, akademisi, maupun instansi terkait agar terus meningkatkan pelatihan dan sosialisasi standar akuntansi yang berlaku agar pelaku UMKM dapat memiliki sumber daya manusia yang berkualitas dalam rangka penyusunan laporan keuangan yang wajar dan memenuhi kewajiban perpajakan.

\section{DAFTAR PUSTAKA}

Azmary, Y. M. P., Hasanah, N., \& Muliasari, I. (2020). Pengaruh kecerdasan spiritual, penerapan akuntansi, pemahaman perpajakan terhadap kepatuhan WPOP UMKM. Jurnal Akuntansi, Perpajakan dan Auditing, 1(1), 134-146. http://pub.unj.ac.id/index.php/japa/article/view/95

Darmawati, D., \& Oktaviani, A. A. (2018). Pengaruh penerapan akuntansi UMKM terhadap kepatuhan wajib pajak UMKM e-Commerce. Seminar Nasional Cendikiawan, 4, 919925. https://trijurnal.lemlit.trisakti.ac.id/index.php/semnas/article/view/3401

Dartini, G. A. A. S., \& Jati, I. K. (2016). Pemahaman akuntansi, transparasi, dan akuntabilitas pada kepatuhan wajib pajak badan. E-Jurnal Akuntansi, 17(3), 2447-2473. https://ojs.unud.ac.id/index.php/Akuntansi/article/view/23702

Dewi, L. G. K., \& Sari, L. G. J. M. (2019). Analisis kesiapan dan pengetahuan dalam penyusunan laporan keuangan berbasis standar akuntansi keuangan EMKM (Studi kasus pada usaha menengah di Kabupaten Buleleng). Jurnal Ilmiah Akuntansi, 4(2), 141-160. https://ejournal.undiksha.ac.id/index.php/JIA/article/view/21900

Divianto, \& Febrianty. (2017). Pengaruh pemahaman pelaku UKM dalam menyusun laporan keuangan terhadap implementasi laporan keuangan berdasarkan SAK ETAP dengan persepsi UKM sebagai moderating variable. International Journal of Social Science 
and

Business,

$1(3)$

166-176.

https://ejournal.undiksha.ac.id/index.php/IJSSB/article/view/11318

Febriani, Y., \& Kusmuriyanto. (2015). Analisis faktor-faktor yang mempengaruhi kepatuhan wajib pajak. Accounting Analysis Journal, 4(4), 1-13. https://journal.unnes.ac.id/sju/index.php/aaj/article/view/9112

Fettry, E. M. S., Felisia., Rahayu, P. A., \& Paramita, M. (2019). Potensi kepatuhan pembayaran pajak pengusaha UMKM berdasarkan PP Nomor 23 Tahun 2018 ( Survei di Kota Bandung ). http://repository.unpar.ac.id/handle/123456789/10090

Ghozali, I. (2013). Analisis aplikasi multivariate dengan program IBM SPSS 21 update PLS Regresi, Edisi 7. Semarang: Badan Penerbit Universitas Diponegoro.

Hair, J. F., Black, W. C., Babin, B. J., \& Anderson, R. E. (2009). Multivariate data analysis, $7^{\text {th }}$ Edition. United States: Prentice Hall.

Ikatan Akuntan Indonesia. (2016). Standar Akuntansi Keuangan Entitas Mikro, Kecil, dan Menengah.

Jayani, D. H. (2020). Berapa sumbangan UMKM terhadap perekonomian Indonesia? Databoks. https://databoks.katadata.co.id/datapublish/2020/05/20/berapa-sumbanganumkm-terhadap-perekonomian-indonesia

Lestari, E. P. (2019). Kesiapan UMKM dalam implementasi SAK EMKM pengrajin mebel Desa Catak Gayam, Mojowarno. JAD: Jurnal Riset Akuntansi dan Keuangan Dewantara, 2(1), 24-33. https://doi.org/10.26533/jad.v2i1.357

LPPI, \& Bank Indonesia. (2015). Profil bisnis Usaha Mikro, Kecil dan Menengah (UMKM). Kerjasama Lembaga Pengembangan Perbankan Indonesia dengan Bank Indonesia. https://pdfslide.tips/documents/profil-bisnis-usaha-mikro-kecil-dan-menengah-iiiprofil-bisnis-usaha-mikro.html

Mardiasmo. (2018). Perpajakan. Yogyakarta: Andi Offset.

Pakpahan, Y. E. (2015). Pengaruh pemahaman akuntansi, pemahaman ketentuan perpajakan dan transparansi dalam pajak terhadap kepatuhan wajib pajak badan. Jurnal Online Mahasiswa (JOM) Bidang Ilmu Ekonomi, 2(2), 1-15. https://jom.unri.ac.id/index.php/JOMFEKON/article/view/9501

Pulungan, L. A. (2020). Analisis pemahaman dan kesiapan pengelola UMKM dalam implementasi laporan keuangan berbasis SAK EMKM (Studi empiris pada UMKM di Kota Medan). Jurnal Pembangunan Perkotaan, 8(1), 51-56. http://ejpp.balitbang.pemkomedan.go.id/index.php/JPP/article/view/77

Putra, Y. M. (2018). Pemetaan penerapan standar akuntansi keuangan EMKM pada UMKM di Kota Tangerang Selatan. Profita: Komunikasi Ilmiah Akuntansi dan Perpajakan, 11(2), 201-217. http://dx.doi.org/10.22441/profita.2018.v11.02.004

Qimyatussa'adah, Nugroho, S. W., \& Hartono, H. R. P. (2020). Pengetahuan dan pemahaman pelaku UMKM atas Standar Akuntansi Keuangan Entitas Mikro, Kecil dan Menengah (SAK EMKM). Monex: Journal of Accounting Research, 9(2), 146-151. https://ejournal.poltektegal.ac.id/index.php/monex/article/view/1874

Risal, Febriati, \& Wulandari, R. (2020). Persepsi pelaku UMKM dalam menyusun laporan keuangan. JAD: Jurnal Riset Akuntansi dan Keuangan Dewantara, 3(1), 16-27. https://ejournal.stiedewantara.ac.id/index.php/JAD/article/view/507

Salmiah, N., Nanda, S. T., \& Adino, I. (2018). Pemahaman pelaku UMKM terhadap SAK EMKM: Survey pada UMKM yang terdaftar di Dinas Koperasi dan UKM Kota Pekanbaru. Jurnal Akuntansi Dewantara, 2(2), 194-204. https://jurnal.ustjogja.ac.id/index.php/akuntansidewantara/article/view/2767

Sholikin, A., \& Setiawan, A. (2018). Kesiapan UMKM terhadap implementasi SAK EMKM (Studi UMKM di Kabupaten Blora). Journal of Islamic Finance and Accounting, 1(2), 35-50. https://doi.org/10.22515/jifa.v1i2.1441 
Sugiyono. (2019). Metode penelitian kuantitatif kualitatif dan R\&D, Edisi 2. Bandung: CV. Alfabeta.

Sumianto, \& Kurniawan, C. H. (2015). Pengaruh pemahaman akuntansi dan ketentuan perpajakan serta transparansi dalam pajak terhadap kepatuhan wajib pajak orang pribadi usahawan pada UKM di Yogyakarta. Modus Journal, 27(1), 41-51. https://doi.org/10.24002/modus.v27i1.567

Sutapa, I. N. (2020). Tingkat penerapan SAK EMKM pada pelaku UMKM dan upaya peningkatan penerapan SAK EMKM dilihat dari persepsi UMKM dan sosialisasi SAK EMKM. Krisna: Kumpulan Riset Akuntansi, 12(1), 63-68. https://doi.org/10.22225/kr.12.1.1847.63-68 